\title{
SISTEM INFORMASI PENOMORAN SURAT (STUDI KASUS FAKULTAS TEKNIK UNIVERSITAS LAMBUNG MANGKURAT)
}

\author{
Dwi Hastuti \\ Program Studi Teknik Informatika \\ Fakultas Teknik \\ Universitas Lambung Mangkurat \\ Banjarmasin, Kalimantan Selatan \\ e-mail: dwi.hastuti@unlam.ac.id
}

\begin{abstract}
ABSTRAK
Surat adalah salah satu media komunikasi yang memegang peranan penting. Selain berfungsi sebagai alat komunikasi, surat juga menjadi dokumen yang penting bagi organisasi. Karena semua bentuk komunikasi resmi dikirim melalui surat. Fakultas Teknik Universitas Lambung Mangkurat merupakan universitas yang terus berkembang di Kalimantan Selatan. Dimana didalamnya dikendalikan oleh organisasi yang mengelola surat sebagai alat komunikasi resmi. Namun, dengan semakin meningkatnya jumlah surat, maka muncullah permasalahan dalam mengelola surat khusunya dalam mengelola nomor surat dan pencarian surat. Dengan menggunakan dan memanfaatkan sistem informasi, penulis mencoba untuk memberikan solusi. Dalam penelitian ini penulis menggunakan pendekatan metode dengan mendesain sistem dengan tool use case diagrams, activity diagrams, dan sequence diagrams, class diagrams. Kemudian, penulis membuat prototype sistem tersebut. Untuk mendukung penelitian ini dibutuhkan data primer seperti dari hasil observasi dan wawancara, sedangkan data sekunder dari dokumen-dokumen yang ada di perusahaan tersebut.
\end{abstract}

Kata Kunci: Sistem Informasi, Penomoran Surat.

\begin{abstract}
Letter is one of the communication media has an important role. Besides having the function of a messenger, the letter also become one of the important documents for an organization. Because all forms of official communication must be submitted by mail. Engineering Faculty of Lambung Mangkurat University is one of the leading universities in South Kalimantan. As a university, its driven by an organization to which the letter became one of the important means of communication. But along the way with the increasing number of letters and the development of the organization, it raises some issues that occur, like mail numbering dan searching. By taking advantage of information systems, author tries to do a study to resolve those problems. In this study the authors use an object-oriented approach a method of designing systems with tools such as use case diagrams, activity diagrams, sequence diagrams, and class diagrams. In addition, the authors use a prototyping approach to software development methods. To Support this research data is needed to determine the solution of the problem. Sources of primary data obtained from direct observation (observation) and interviews, while the secondary data obtained from the documents that exist in them.
\end{abstract}

Keywords: Information Systems, Mail Numbering.

\section{Pendahuluan}

Pengelolaan surat merupakan hal yang penting bagi sebuah organisasi. Melalui surat setiap bagian dari organisasi baik yang berada di dalam maupun di luar organisasi melakukan komunikasi. Surat yang terdapat pada organisasi tersebut berupa surat masuk dan surat keluar. Berbagai informasi penting mengenai kegiatan organisasi disampaikan kepada pihak-pihak yang membutuhkan melalui surat.

Surat adalah sebuah alat komunikasi tertulis yang digunakan oleh pengirim untuk mengirimkan berita atau informasi kepada penerima. Surat juga memiliki fungsi dokumentasi yang berisi rekaman tentang aktivitas suatu organisasi. Surat pula dapat dijadikan sebuah bukti atau dasar untuk melakukan tindakan tertentu karena memiliki tanda keabsahan perintah yang kuat, yaitu tanda tangan pembuatnya. Oleh karena itu penanganan pengelolaan surat perlu mendapatkan perhatian yang tinggi, terutama pada kegiatan pengarsipan untuk menjaga agar surat dapat digunakan kapan saja. Fakultas Teknik Universitas Lambung Mangkurat merupakan perguruan tinggi yang perkembangannya sangat pesat. Hal ini terwujud dengan adanya sinergi yang baik diantara setiap bagian rektorat yaitu rektor, wakil rektor I (WR-I) bidang akademik, wakil rektor II (WR-II) bidang administrasi, kepegawaian dan keuangan dan wakil rektor III (WR-III) bidang kemahasiswaan serta fakultas, program studi dan semua pihak terkait baik pihak dalam maupun luar universitas. Sinergi yang baik ini diupayakan dengan adanya komunikasi, 
terutama melalui surat. Pengelolaan surat yang yang dilakukan oleh perusahaan tersebut berkaitan dengan rektorat, fakultas, program studi, departemen lain, mahasiswa dan pihak eksternal perusahaan.

Namun saat ini dalam pelaksanaannya pengelolaan surat banyak mengalami kendala. Seperti pada saat pengagendaan surat masuk yang diterima dan surat keluar yang akan dikirimkan, penomoran surat sulit dilakukan karena surat dicatat pada buku agenda konvensional. Pengarsipan dokumen fisik surat belum optimal, terutama pada saat pencarian berkas arsip surat membutuhkan waktu cukup lama karena posisi penyimpanan arsip surat bercampur dan tidak memiliki pengkodean khusus. Hal tersebut berakibat membutuhkan waktu yang yang cukup lama dan biaya lebih, karena harus digandakan terlebih dahulu untuk kemudian disampaikan kepada penerima surat. Mengingat pentingnya peranan pengelolaan surat, sudah seharusnya surat tersebut dikelola dengan baik sejak surat itu diterima atau dikeluarkan. Oleh karena itu diperlukan adanya sistem yang dapat digunakan untuk mengelola kegitan surat menyurat secara terpadu. Sistem tersebut adalah Sistem Informasi Penomoran Surat.

\section{LANDASAN TEORI}

\section{Sistem Informasi}

Menurut Richardus Eko Indrajit (2000:3) Sistem Informasi adalah suatu kumpulan dari komponen-komponen dalam perusahaan atau organisasi yang berhubungan dengan proses penciptaan dan pengaliran informasi. Menurut Robert A. Leitch dan K. Roscoe Davis (Jogiyanto, 2005:11) Sistem Informasi adalah suatu sistem di dalam suatu organisasi yang mempertemukan kebutuhan pengolahan transaksi harian, mendukung operasi, bersifat manajerial dan kegiatan strategi dari suatu organisasi dan menyediakan pihak luar tertentu dengan laporan-laporan yang diperlukan. Menurut Abdul Kadir (2003:10) Sistem Informasi adalah sejumlah komponen (manusia, komputer, teknologi informasi, dan prosedur kerja), ada sesuatu yang diproses (data menjadi informasi), dan dimaksudkan untuk mencapai suatu sasaran atau tujuan. Setelah diuraikan mengenai definisi sistem dan informasi maka secara umum sistem informasi didefinisikan sebagai kumpulan dari sub-sub sistem, baik fisik maupun non fisik yang saling berhubngan dan bekerjasama secara harmonis untuk mencapai suatu tujuan yaitu mengolah data menjadi informasi yang berguna. Komponen-komponen sistem informasi menurut Jogiyanto (2005:12), terdiri dari :

1. Hardware

Kumpulan dari perangkat keras yang terlihat memungkinkan dapat membentuk sistem seperti komputer, printer dan jaringan.

2. Software

Kumpulan dari perintah-perintah/fungsi yang ditulis dengan aturan tertentu, memerintahkan komputer agar melaksanakan fungsi tertentu.

3. Data

Bahan dasar dari suatu informasi berupa fakta yang mengangkat kejadian-kejadian nyata dan dituangkan kedalam suatu simbol.

4. Prosedur

Suatu tahapan yang berupa urutan kegiatan yang saling berhubungan untuk mencapai tujuan yang berupa suatu dokumen prosedur seperti : buku petunjuk operasional dan teknis.

5. Manusia

Merupakan pelaksana dari suatu sistem informasi seperti : Operator, Programmer, Analis, Desainer dan sebagainya.

\section{Surat}

Surat merupakan salah satu sara komunikasi secara tertulis yang berbentuk lembaran kertas yang memuart suatu informasi yang hendak disampaikan oleh seseorang kepada orang lain. Informasi tersebut dapat berupa pemberitahuan, pertanyaan, permintaan, laporan, peringatan, dan sebagainya. Selain sebagai alat komunikasi, surat juga dapat berfungsi sebagai:

1. Alat bukti tertulis, misalnya surat perjanjian, surat keputusan, dan sebagainya.

2. Alat pengingat, misalnya surat yang telah diarsipkan.

3. Dokumentasi historis, misalnya surat dalam arsip lama yang digunakan kembali untuk penyelidikan mengenai masa lalu.

4. Pedoman tindakan, misalnya surat perintah, surat tugas, surat edaran, dan sebagainya.

5. Jaminan keamanan, misalnya surat keterangan jalan. 
6. Duta atau wakil organisasi, maksudnya surat mencerminkan keadaan mentalitas, jiwa, dan kondisi intern dari organisasi yang mengeluarkannya. Surat-surat yang dikirim oleh suatu kantor sering merupakan satusatunya hubungan kantor yang satu dengan kantor yang lain. Karena itu, perlu sekali surat dirumuskan dan ditata sedemikian rupa sehingga menciptakan kesan baik dan berwibawa.

\section{Jaringan Komputer}

Jaringan komputer adalah sebuah sistem yang terdiri atas komputer, software dan perangkat jaringan lainnya yang bekerja bersama-sama untuk mencapai suatu tujuan yang sama. Tujuan dari jaringan komputer adalah berbagi sumber daya.Informasi dan data bergerak melalui media transmisi jaringan sehingga memungkinkan pengguna jaringan komputer dapat saling bertukar dokumen dan data, mencetak pada printer yang sama dan bersama sama menggunakan hardware/software yang terhubung dengan jaringan. Tiap komputer, printer atau perangkat yang terhubung dengan jaringan disebut node. Sebuah jaringan komputer dapat memiliki dua, puluhan, ribuan atau bahkan jutaan node.

\section{Metode Penelitian}

Metode ialah suatu kerangka kerja untuk melakukan suatu tindakan, atau suatu kerangka berfikir menyusun gagasan, yang beraturan, berarah dan berkonteks, yang patut (relevant) dengan maksud dan tujuan. Secara ringkas, metode ialah suatu sistem berbuat. Karena berupa sistem maka metode merupakan seperangkat unsurunsur yang membentuk suatu kesatuan. (Notohadiprawiro, 2006). Sebelum melakukan penelitian kita perlu menentukan rencana untuk memilih sumber-sumber dan jenis informasi yang dipakai untuk menjawab pertanyaan penelitian. Desain penelitian merupakan kerangka kerja untuk merinci hubungan-hubungan antara variabel dalam penelitian dan merupakan blue print yang memberi garis besar dari setiap prosedur penelitian mulai dari masalah/pertanyaan penelitian sampai dengan analisis data.

\section{Jenis dan Metode Pengumpulan Data}

Dalam menunjang penelitian ini diperlukan data untuk menentukan pemecahan masalah yang ditemukan.Sumber data primer diperoleh dari pengamatan langsung (observasi) dan wawancara, sedangkan data sekunder diperoleh dari dokumen-dokumen yang ada di perusahaan.

\section{Sumber Data Primer (Wawancara, Observasi)}

a. Observasi

Pada saat melakukan pengamatan langsung (observasi) peneliti mengamati setiap kegiatan yang terjadi pada subjek penelitian.Pada penelitian ini, penliti melakukan pengamatan langsung di perusahaan.

b. Wawancara

Wawancara dilakukan dengan cara melakukan tanya jawab secara lisan dengan orang-orang yang terlibat dan berhubungan dengan objek penelitian. Peneliti mengumpulkan dan mencari informasi dengan cara melakukan tanya jawab secara lisan dengan pengelola sekretariat perusahaan.

\section{Sumber Data Sekunder}

Data sekunder didapatkan dengan cara mempelajari data yang telah tersedia di perusahaan. Data sekunder yang diperoleh mengenai struktur organisasi, tugas, fungsi, prosedur pengelolaan surat, jurnal surat, dan arsip surat.

\section{Metode Pendekatan dan Pengembangan Sistem}

Dalam pembuatan sistem informasi, diperlukan suatu metodologi yang dapat digunakan sebagai panduan dalam membangun sebuah sistem yaitu, metodependekatan dan pengembangan sistem. Dalam penelitian ini peneliti menggunakan metode pendekatan sistem berorientasi objek dan untuk metode pengembangan sistem menggunakan metode pengembangan sistem Prototype.

\section{Metode Pendekatan Sistem}

Metode pendekatan sistem yang digunakan adalah pendekatan sistem berorientasi objek. Metode pendekatan sistem berorientasi objek adalah suatu strategi pembangunan perangkat lunak yang mengorganisasikan perangkat lunak sebagai kumpulan objek yang berisi data dan operasi yang diberlakukan terhadapnya. Metode pendekatan sistem berorientasi objek merupakan suatu cara bagaimana sistem perangkat lunak dibangun melalui pendekatan 
objek secara sistematis. Metode pendekatan sistem berorientasi objek didasarkan pada penerapan prinsip prinsip pengelolaan kompleksitas. Metode berorientasi objek meliputi rangkaian aktivitas analisis berorientasi objek, perancangan berorientasi objek, pemrograman berorientasi objek dan pengujian berorientasi objek. (Rosa dan Shalahudin, 2011).

\section{Metode Pengembangan Sistem}

Untuk membangun suatu sistem yang kompleks secara sistematis dan terintegrasi, dibutuhkan metode-metode pembangunan sistem agar dapat menuntun pembuat untuk menghasilkan suatu sistem standar. Untuk mengembangkan suatu sistem informasi, kebanyakan orang menggunakan suatu metodologi pengembangan sistem. Prototyping merupakan salah satu metode pengembangan sistem yang banyak digunakan. Dengan metode prototyping ini pengembang dan pengguna dapat saling berinteraksi selama proses pembuatan sistem. Sering terjadi seorang pengguna hanya mendefinisikan secara umum apa yang dikehendakinya tanpa menyebutkan secara detil output apa saja yang dibutuhkan, pemrosesan dan data-data apa saja yang dibutuhkan. Sebaliknya disisi pengembang kurang memperhatikan efesiensi algoritma, kemampuan sistem operasi dan interface yang menghubungkan manusia dan komputer. Untuk mengatasi ketidakserasian antara pengguna dan pengembang, maka harus dibutuhakan kerjasama yanga baik diantara keduanya sehingga pengembang akan mengetahui dengan benar apa yang diinginkan pengguna dengan tidak mengesampingkan segi-segi teknis dan pengguna akan mengetahui proses-proses dalm menyelasaikan sistem yang diinginkan. Dengan demikian akan menghasilkan sistem sesuai dengan jadwal waktu penyelesaian yang telah ditentukan. Kunci agar metode prototype ini berhasil dengan baik adalah dengan mendefinisikan aturan - aturan main pada saat awal, yaitu pengguna dan pengembang harus setuju bahwa prototype dibangun untuk mendefinisikan kebutuhan. Prototype akan dihilangkan sebagian atau seluruhnya dan perangkat lunak aktual aktual direkayasa dengan kualitas dan implementasi yang sudah ditentukan.

\section{Alat Bantu Analisis dan Perancangan}

Alat bantu analisis dan perancangan yang digunakan untuk memudahkan dalam perancangan sistem informasi ini adalah Unified Modelling Language (UML). UML didefinisikan sebagai solusi notasi diagram untuk mengambarkan artefak pada perancangan sistem berorientasi objek. Dengan UML kita bisa memvisualisasikan, menetapkan, membuat dan mendokumentasikan aplikasi sofware kita. Saat sistem software menjadi lebih besar dan lebih kompleks, kita perlu untuk mengatur kekompleksan tersebut dan dalam arti menyederhanakannya sehingga kita bisa lebih mengertinya. (Dharwiyanti : 2003). Seperti bahasa-bahasa lainnya, UML Mendefinisikan notasi dan syntax/semantik. Notasi UML merupakan sekumpulan bentuk khusus untuk menggambarkan berbagai diagram piranti lunak. Setiap bentuk memiliki makna tertentu, dan UML syntax mendefinisikan bagaimana bentuk-bentuk tersebut dapat dikombinasikan. Diagram-diagram yang terdapat di dalam pemodelan UML adalah sebagai berikut :

1. Diagram Use Case

Diagram Use Case menggambarkan fungsionalitas yang diharapkan dari sebuah sistem. Yang ditekankan adalah "apa" yang diperbuat sistem, dan bukan "bagaimana". Sebuah use case merepresentasikan sebuah interaksi antara aktor dengan sistem.

2. Diagram Aktivitas

Diagram aktivitas menggambarkan berbagai alur aktivitas dalam sistem yang sedang dirancang, bagaimana masing-masing alur berawal, decision yang mungkin terjadi, dan bagaimana mereka berakhir. Diagram aktivitas juga dapat menggambarkan proses paralel yang mungkin terjadi pada beberapa eksekusi. Diagram aktivitas merupakan state diagram khusus, di mana sebagian besar state adalah action dan sebagian besar transisi di-trigger oleh selesainya state sebelumnya (internal processing). Oleh karena itu, diagram aktivitas tidak menggambarkan behaviour internal sebuah sistem (dan interaksi antar subsistem) secara eksak, tetapi lebih menggambarkan proses - proses dan jalur-jalur aktivitas dari level atas secara umum.

3. Diagram Sequence

Diagram sequence menggambarkan interaksi antar objek di dalam dan di sekitar sistem (termasuk pengguna, display, dan sebagainya) berupa message yang digambarkan terhadap waktu. Diagram sequence terdiri atas dimensi vertikal (waktu) dan dimensi horizontal (objek-objek yang terkait). Diagram sequence biasa digunakan untuk menggambarkan skenario atau rangkaian langkah-langkah yang dilakukan sebagai respon dari sebuah event untuk menghasilkan dan perubahan apa saja yang terjadi secara internal dan output apa yang dihasilkan.

4. Diagram Kelas 
Diagram kelas adalah sebuah spesifikasi yang jika diinstansiasi akan menghasilkan sebuah objek dan merupakan inti dari pengembangan dan desain berorientasi objek. Diagram kelas menggambarkan keadaan (atribut/properti) suatu sistem, sekaligus menawarkan layanan untuk Memanipulasi keadaan tersebut (metoda/fungsi). Diagram kelas menggambarkan struktur dari deskripsi class, package, dan objek beserta hubungan satu sama lain seperti containment, pewarisan, asosiasi, dan lain- lain. Diagram kelas memiliki tiga area pokok:

a. Nama (dan stereotype)

b. Atribut

c. Metoda

\section{Pengujian Software}

Pengujian perangkat lunak adalah proses pemeriksaan atau evaluasi sistem atau komponen sistem secara manual atau otomatis untuk memverifikasi apakah sistem memenuhi kebutuhan-kebutuhan yang dispesifikasikan atau mengidentifikasi perbedaan-perbedaan antara hasil yang diharapkan dengan hasil yang terjadi (Hariyanto: 2004). Sasaran pengujian adalah penemuan semaksimum mungkin kesalahan dengan usaha yang dapat dikelola pada rentang waktu realistik. Pengujian perangkat lunak merupakan tahap kritis dalam penjaminan kualitas perangkat lunak dan merupakan review menyeluruh terhadap spesifikasi perancangan dan pengkodean (Hariyanto: 2004).

\section{HASIL}

Diagram Usecase

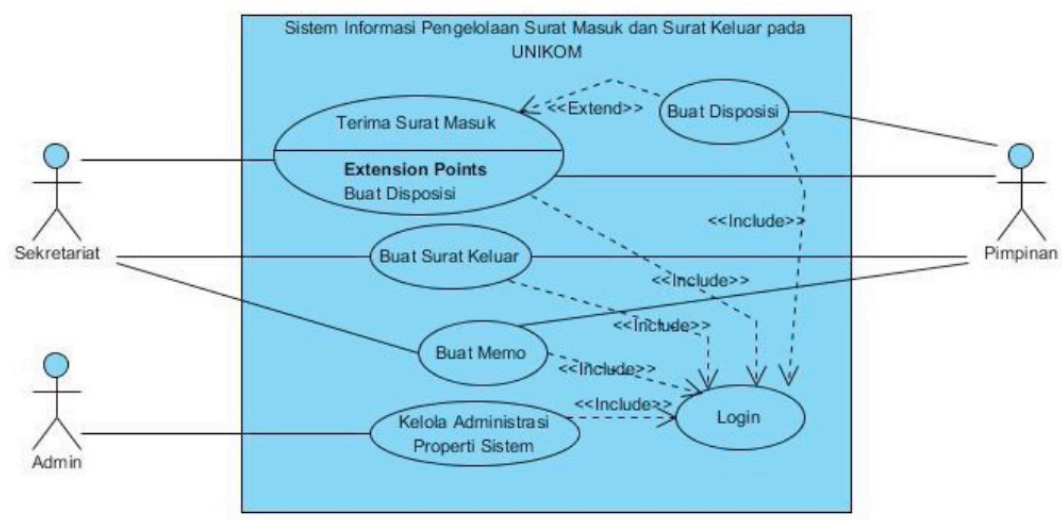

Diagram Aktivitas

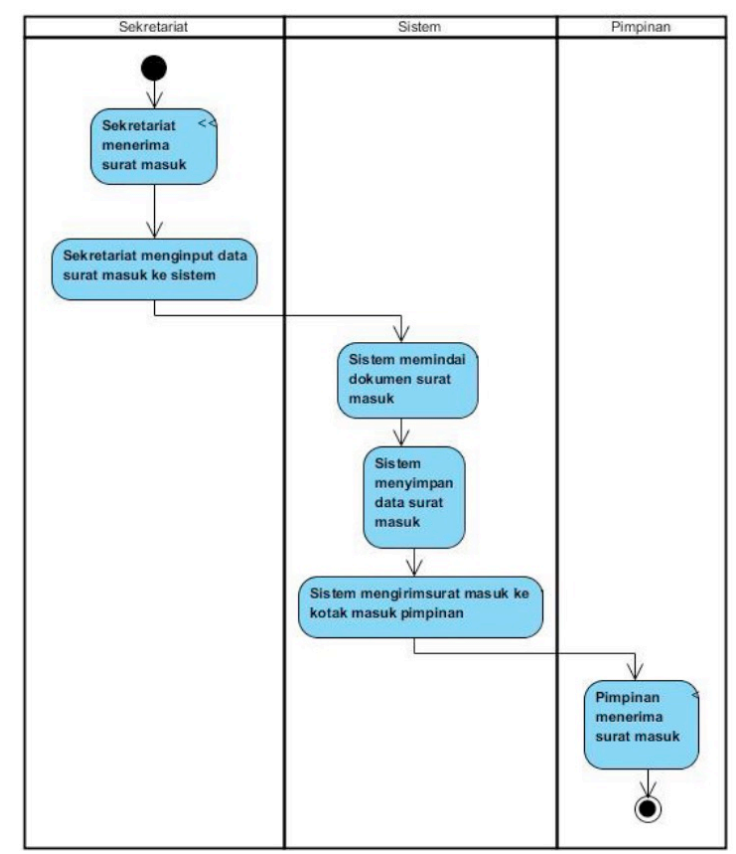


Diagram Sequence

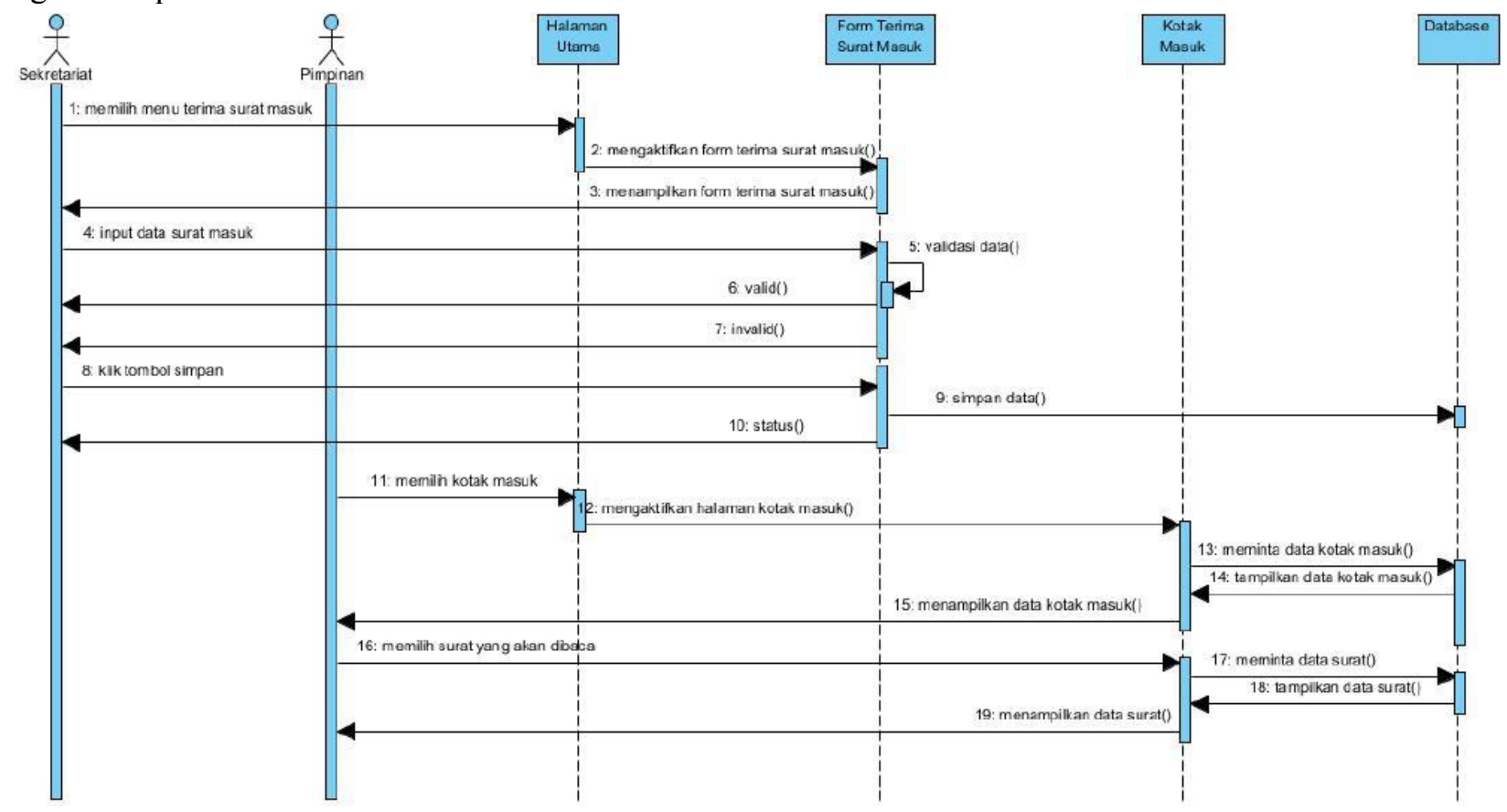

Diagram Class

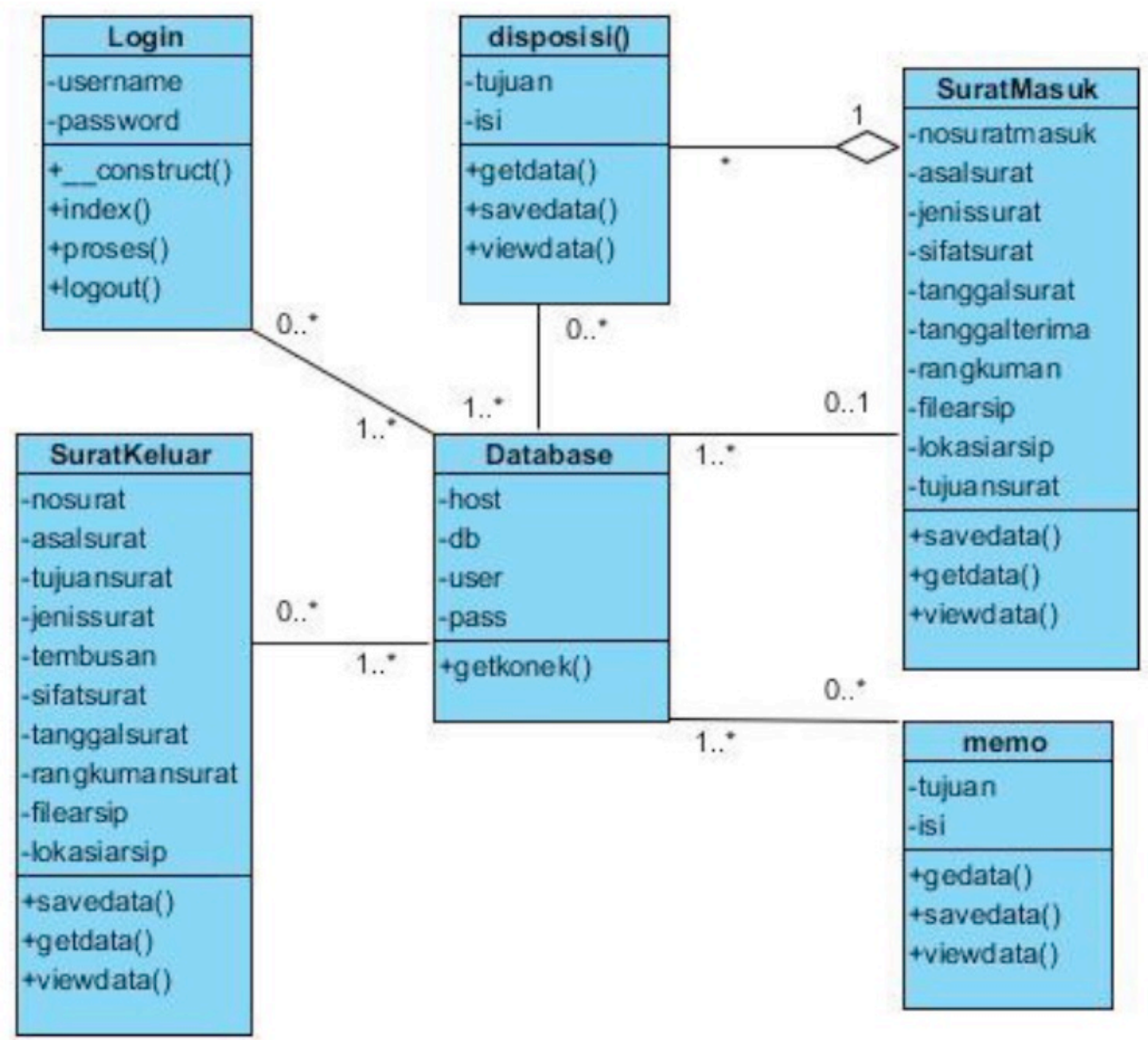

Interface 


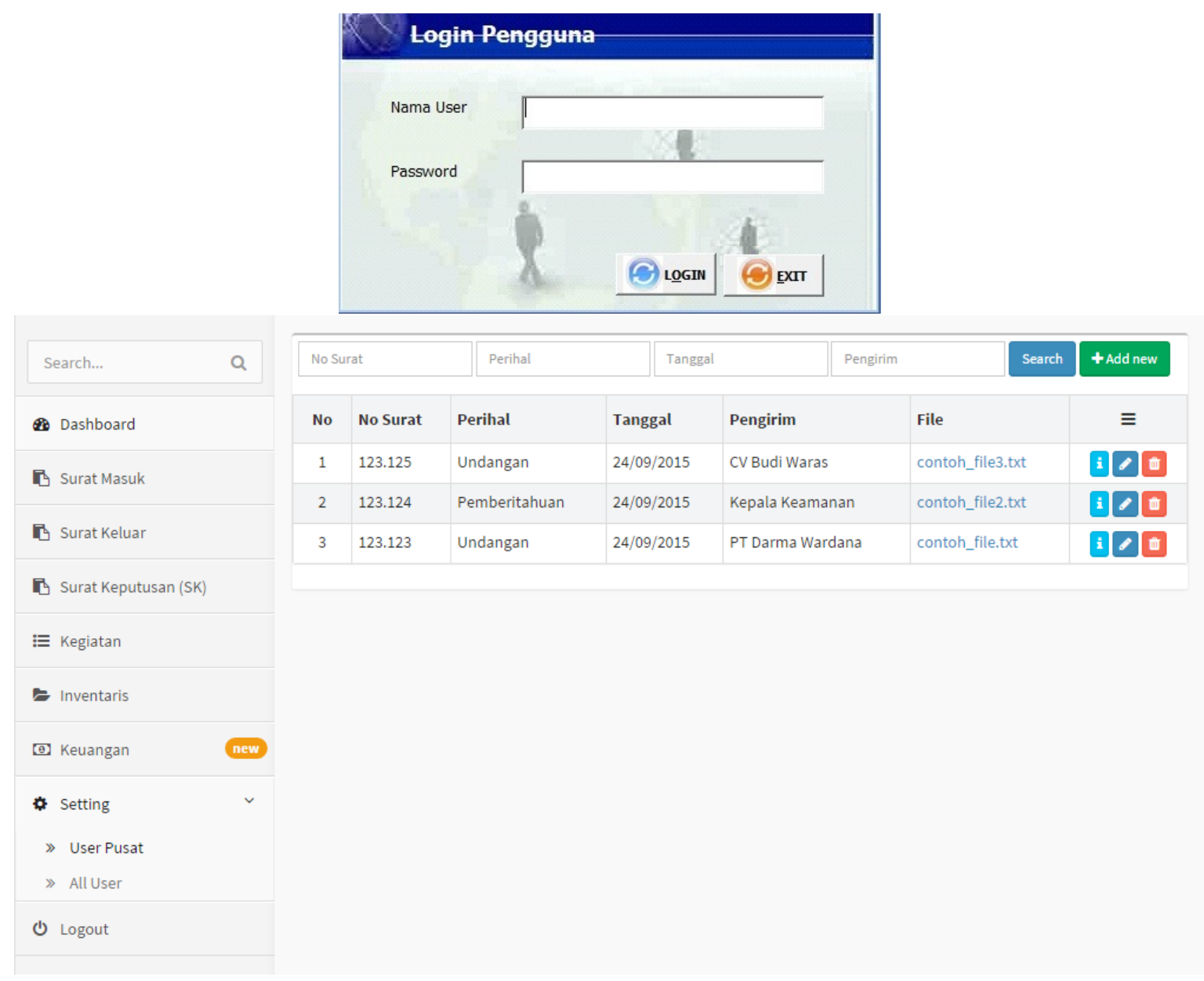

\section{KeSIMPUlaN}

Berdasarkan penelitian yang telah dilaksanakan, penulis menarik kesimpulan sebagai berikut :

1. Sistem yang dirancang ini adalah sistem informasi pengelolaan surat secara digital.

2. Implementasi dari perancangan sistem informasi ini dengan cara membuat kode program dengan menggunakan bahasa pemrograman. Sehingga menghasilkan sebuah sistem informasi pengelolaan surat.

3. Pengujian yang dilakukan terhadap setiap fungsi sistem dengan menggunakan pengujian blackbox menunjukkan hasil yang baik. Karena setiap fungsi yang dibuat dapat digunakan dengan baik dan sesuai dengan kebutuhan.

\section{DAFTAR Pustaka}

[1] Amsyah, Dra. Zulkifli, ML.S. (2005). Manajemen Sistem Informasi. Jakarta : PT. Gramedia Pustaka Utama.

[2] Fatta, Hanif Al. (2007). Analisis dan Perancangan Sistem Informasi untuk Keunggulan Bersaing Perusahaan dan Organisasi Modern. Yogyakarta : C.V ANDI OFFSET.

[3] Gaol, Chr. Jimmy L. (2008). Sistem Informasi Manajemen : Pemahaman dan Aplikasi, Yogyakarta : C.V ANDI PT. GRASINDO.

[4] Hakim, Lukmanul. (2010). Membangun Web Berbasis PHP dengan Framework CodeIgniter. Lokomedia.Yogyakarta.

[5] Jogiyanto HM, MBA, Akt. (2005). Analisis dan Desain . Andi. Yogyakarta.

[6] Nugroho, Adi (2010). Rekayasa Perangkat Lunak Berorientasi Objek dengan Metode USDP (Unified Software Development Process).Penerbit Andi. Yogyakarta.

[7] Rosa A.S dan M. Shalahuddin. 2011. Rekayasa Perangkat Lunak Terstruktur dan Berorientasi Objek. Modula 2011. Bandung.

[8] Simarmata, Janner (2010). Rekayasa Perangkat Lunak. Yogyakarta : C.V ANDI OFFSET. ISBN : $978-979-29-1347$ $-7$.

[9] Yakub. (2012). Pengantar Sistem Informasi Ed.I.Graha Ilmu. Yogyakarta. ISBN: 978-979-756-807-8. 